\title{
Synchronization of ovulation in crossbred dairy heifers using gonadotrophin-releasing hormone agonist, prostaglandin F2 $\alpha$ and human chorionic gonadotrophin or estradiol benzoate
}

\section{Castilho ${ }^{1}$, \\ A.L.G. Gambini' ${ }^{1}$, \\ P. Fernandes ${ }^{1}$, L.A. Trinca ${ }^{2}$, \\ A.B. Teixeira ${ }^{1}$ and \\ C.M. Barros ${ }^{1}$}

\author{
Departamentos de ${ }^{1}$ Farmacologia and \\ 2Bioestatística, Instituto de Biociências, \\ Universidade Estadual Paulista, Botucatu, SP, Brasil
}

\section{Correspondence \\ C.M. Barros \\ Departamento de Farmacologia Instituto de Biociências, UNESP 18618-000 Botucatu, SP Brasil \\ Fax: +55-14-821-3744 \\ E-mail: cmbarros@ ibb.unesp.br \\ Presented at the "30th Annual Meeting of the Society for the Study of Reproduction", Portland, O regon, USA, August 1997 (Biology of Reproduction, 56 (Suppl 1): 450).}

Research supported by FAPESP (No. 98/01186-9) and CAPES.

Received March 31, 1999 Accepted November 4, 1999

\section{Abstract}

Girolando (Gir x Holstein) is a very common dairy breed in Brazil because it combines the rusticity of Gir (Bos indicus) with the high milk yield of Holstein (Bos taurus). The ovarian follicular dynamics and hormonal treatments for synchronization of ovulation and timed artificial insemination were studied in Girolando heifers. The injection of a gonadotrophin-releasing hormone $(\mathrm{GnRH})$ agonist was followed 6 or 7 days (d) later by prostaglandin F2 $\alpha$ (PGF2 $\alpha$ ). Twentyfour hours after PGF2 $\alpha$ injection either human chorionic gonadotropin (hCG, GPh-d6 and GPh-d7 groups) or estradiol benzoate (EB, GPE-d6 and GPE-d7 groups) was administered to synchronize ovulation and consequently allow timed artificial insemination (AI) 24 and $30 \mathrm{~h}$ after hCG and EB injection, respectively. Follicular dynamics in Girolando heifers was characterized by the predominance of three follicular waves (71.4\%) with sizes of dominant follicles (10-13 mm) and corpus luteum (approximately $20 \mathrm{~mm}$ ) similar to those for Bos indicus cattle. In the GnRH-PGF-hCG protocol, hCG administration induced earlier ovulation $(67.4 \mathrm{~h}, \mathrm{P}<0.01)$ compared to the control group (GnRH-PGF) and a better synchronization of ovulation, since most of it occurred within a period of 12 to $17 \mathrm{~h}$. Pregnancy rate after timed AI was 42.8 (3/7, GPh-d6) to 50\% (7/14, GPh-d7). In contrast, estradiol benzoate (GnRH-PGF-EB protocol) synchronized ovulation of only 5 of 11 heifers from the GPE-d7 group and of none (0/7) from the GPE-d6 group, which led to low pregnancy rates after timed AI (27.3 and $0 \%$, respectively). However, since a small number of Girolando heifers was used to determine pregnancy rates in the present study, pregnancy rates should be confirmed with a larger number of animals.
Key words

- Follicle

- Corpus luteum

- O vulation

- hCG

- GnRH

- Artificial insemination 


\section{Introduction}

Zebu cattle (Bos indicus) is predominant in Brazil and other tropical and subtropical regions. Girolando (Gir x Holstein) is a very common dairy breed in Brazil because it combines the rusticity of Gir (Bos indicus) with the high milk yield of Holstein (Bos taurus). One of the most important factors for a successful artificial insemination (AI) program is the detection of estrus, which requires time and trained personnel. In the last decade the characterization of bovine follicular dynamics by ultrasonography has provided a rational basis for pharmacological manipulation of the estrous cycle in order to synchronize ovulation and allow $\mathrm{AI}$ at a predetermined time (timed $\mathrm{AI})$ regardless of estrous behavior.

The gonadotrophin-releasing hormone $(\mathrm{GnRH})$ analogs have been shown to induce follicle luteinization or ovulation, followed by the emergence of a new follicular wave (1). GnRH analog administration followed 7 days (d) later by prostaglandin F2 $\alpha$ (PGF2 $\alpha$ ) is a synchronization system whereby the animals show a better homogeneity of follicular development at the time of induced luteolysis (2). If a second injection of GnRH agonist is administered 36 to $48 \mathrm{~h}$ following PGF $2 \alpha$ administration the ovulation is synchronized (3-5) and timed AI 16 to $24 \mathrm{~h}$ after the second dose of GnRH results in pregnancy rates similar to those observed in cows bred during normal estrus (4-7). Pursley et al. (3) reported that pregnancy rates after timed AI were similar to those for cows bred $12 \mathrm{~h}$ after estrus detection (37.8 vs 38.9\%). On the other hand, Roy and Twagiramungu (8), waiting only 6 days between the first GnRH injection and PGF2 $\alpha$ administration, observed a high pregnancy rate $(62.2 \%)$ in fixed-time AI beef heifers.

Therefore, the main objectives of the present study were to characterize follicular dynamics in Girolando heifers and to develop hormonal treatments for the efficient synchronization of ovulation to allow timed AI in heifers.

\section{Material and Methods}

\section{Location and animals}

The experiments were carried out on a private farm (Americana) located $50 \mathrm{~km}$ from Botucatu, São Paulo State, Brazil (latitude $22^{\circ} 51^{\prime} \mathrm{S}$, longitude $48^{\circ} 26^{\prime} \mathrm{W}$ ). During the last 20 years, the mean annual temperature in Botucatu was $20.6^{\circ} \mathrm{C}$ and the mean temperatures for the warmest and coldest months were $23.6^{\circ}$ and $17.4^{\circ} \mathrm{C}$, respectively.

Girolando heifers aged 20 to 30 months were used in four experiments (Exp.). Body weights were approximately $300 \mathrm{~kg}$ (Exp. I and II), $295 \pm 6.6 \mathrm{~kg}$ (Exp. III) and $392 \pm 9.4$ $\mathrm{kg}$ (Exp. IV). The animals were maintained on pasture (Brachiaria decumbens) with ad libitum mineral salt supplementation. Heifers from Exp. I and II also had access to a ration of $30 \%$ napier grass, $50 \%$ corn and $20 \%$ soybean $\left(4 \mathrm{~kg}\right.$ heifer ${ }^{-1}$ day $\left.^{-1}\right)$ for the duration of the experiments.

\section{Experiment I}

Girolando heifers $(\mathrm{N}=20)$ had their estrous cycle synchronized by two intramuscular (im) injections of PGF2 $\alpha$ (dinoprost trometamine, $25 \mathrm{mg}$, Lutalyse $^{\circledR}$, Upjohn, São Paulo, SP, Brazil) administered 11 days apart. After estrus detection, follicle and corpus luteum (CL) development was monitored by daily ultrasonography (Aloka SSD-500, 7.5 $\mathrm{MHz}$ linear transducer) in 14 heifers during a complete estrous cycle. Ovarian maps were drawn to record the relative position of follicles $(\geq 4 \mathrm{~mm})$ and CL as described previously (9).

\section{Experiment II}

Approximately ten days after the end of Exp. I (i.e., 7 to 12 days after ovulation) the same heifers $(\mathrm{N}=14)$ were treated intramuscularly with $8 \mu \mathrm{g}$ of buserelin acetate, a GnRH agonist (Conceptal ${ }^{\circledR}$, Hoechst Roussel 
Veterinária, São Paulo, SP, Brazil, d 0), followed 7 days later by PGF2 $\alpha$ (25 mg dinoprost trometamine, im, Lutalyse ${ }^{\circledR}$, Upjohn, $d 7$ ), and $24 \mathrm{~h}$ after PGF2 $\alpha$ administration they received human chorionic gonadotropin (hCG) (1,000 IU iv; $2000 \mathrm{IU}$ im; Vetecor $^{\circledR}$, Serono Veterinária, São Paulo, SP, Brazil, d 8, GPh-d7 group). The hCG dose was split, and 1,000 IU was given $i v$ to simulate the quick increase in luteinizing hormone (LH) that occurs at the time of the ovulatory surge, and 2,000 IU was given im to maintain LH-like activity for an extended period of time. All heifers were inseminated artificially $20 \mathrm{~h}$ after hCG injection without estrus detection. Pregnancy was diagnosed by ultrasonography at approximately 30 days postinsemination.

Follicular development was examined daily by ultrasonography until hCG injection and then every $6 \mathrm{~h}$ until ovulation during the following 6 days. The time of ovulation was considered as the average between the last time the ovulatory follicle was seen and the first time that it was not observed on the ultrasound screen.

Blood samples $(10 \mathrm{ml})$ were collected into heparinized tubes just before each hormonal treatment and immediately placed on ice. Plasma was separated by centrifugation within $4 \mathrm{~h}$ and then stored at $-20^{\circ} \mathrm{C}$ until the time for progesterone radioimmunoassay (RIA). The CL was considered to be undergoing regression when plasma progesterone concentration declined $50 \%$ or more from mid-luteal phase levels to concentrations $\leq 1.5 \mathrm{ng} / \mathrm{ml}$ (10).

\section{Experiment III}

Twenty-three cycling heifers (with a visible CL by ultrasonography) were allocated to two groups: GP-d7 (control, $\mathrm{N}=12$ ) and GPE-d7 $(\mathrm{N}=11)$.

The animals were treated at random stages of the estrous cycle with a GnRH analog $(8$ $\mu \mathrm{g}$ Conceptal ${ }^{\circledR}, i m, \mathrm{~d} 0$ ) followed by PGF $2 \alpha$ 7 days later $\left(25 \mathrm{mg}\right.$ Lutalyse $^{\circledR}$, im, d 7). After
PGF2 $\alpha$ injection heifers from the GP-d7 (control group) were observed three times a day to detect estrus and AI was performed 12 $h$ later. Twenty-four hours after PGF $2 \alpha$ injection heifers from the GPE-d7 group received estradiol benzoate (EB, $0.75 \mathrm{mg}$, im, Estrogin ${ }^{\circledR}$, Farmavet, São Paulo, SP, Brazil, $\mathrm{d} 8$ ) and were inseminated $30 \mathrm{~h}$ later without estrous detection. Blood samples and ultrasonography were performed as indicated in Exp. II.

\section{Experiment IV}

Twenty-one heifers at random stages of the estrous cycle were divided into three groups (GP-d6, GPE-d6 and GPh-d6) and received hormonal treatments similar to those described in Exp. II (group GPh-d7) and III (groups GP-d7 and GPE-d7), except that PGF2 $\alpha$ injection occurred 6 days after GnRH administration instead of 7 days as in Exp. II and III. Heifers from groups GP-d6, GPE-d6 and $\mathrm{GPh}-\mathrm{d} 6$ were inseminated approximately $12 \mathrm{~h}$ after heat detection, $24 \mathrm{~h}$ after EB injection and $30 \mathrm{~h}$ after hCG injection, respectively. Blood samples were obtained and ultrasonography was performed as indicated in Exp. II.

\section{Progesterone radioimmunoassay (RIA)}

Progesterone RIA was performed according to a method previously described (9). Antiserum to bovine progesterone was a gift from Dr. Magaly Manzo (Faculdade de Ciências Veterinárias Maracay, Venezuela) The intra- and the inter-assay coefficients of variation were 4.4 and $11.9 \%$, respectively, and the sensitivity of the assay was $0.23 \pm$ $0.02 \mathrm{ng} / \mathrm{ml}$.

\section{Statistical analysis}

Data were analyzed using the Statistical Analysis System (11). ANOVA considering animal as a block and comparisons of aver- 
ages (Tukey test) were used to analyze wave length, maximum diameter, growth and atresia rate of the dominant follicle in heifers with 3 follicular waves (Exp. I). The F-test was used to compare the synchronization of ovulation among groups in Exp. III and IV. The Wilcoxon-Mann-Whitney test (12) was used to compare the interval from PGF $2 \alpha$ administration to ovulation.

\section{Results}

\section{Experiment I}

Follicular dynamics in Girolando heifers was characterized by three follicular waves (71.4\%); two heifers exhibited 2 waves (14.3\%), one showed 4 waves (7.1\%) and another animal had a short estrous cycle. Consequently, statistical analysis was performed only in the animals with three follicular waves. The dominant follicle from the second wave was smaller when compared to dominant follicles from the first and third waves $(\mathrm{P}<0.01)$. The third wave was shorter $(\mathrm{P}<0.01)$ than the others and became the ovulatory follicle. Growth and atresia rates did not differ among dominant follicles. The maximum diameter of the CL was approximately $20 \mathrm{~mm}$ and the interovulatory interval was $20.6 \pm 0.4$ days (Table 1).

\section{Experiment II}

The injection of a GnRH agonist induced ovulation in $50 \%(7 / 14)$ of the animals and follicular atresia in the remaining ones. The emergence of a new follicular wave occurred $2.1 \pm 0.1$ days after GnRH injection in all heifers.

The sharp decline in progesterone concentrations $(<1.5 \mathrm{ng} / \mathrm{ml})$ indicates that PGF $2 \alpha$ injection caused luteolysis in 11 of 14 heifers (Figure 1), i.e., $21 \%$ of the heifers did not respond to PGF $2 \alpha$ administration.

PGF2 $\alpha$ followed $24 \mathrm{~h}$ later by hCG administration induced ovulation in 12 of 14
(85.7\%) heifers. The interval between hCG injection and ovulation was $31.6 \pm 3.9 \mathrm{~h}$ and 10 of 12 ovulated within a period of $17 \mathrm{~h}$. In two heifers the ovulation was not synchronized by the hormonal treatments and occurred 11.6 or $68.4 \mathrm{~h}$ after hCG injection. The pregnancy rate after timed AI was 50\% (7 of 14).

\section{Experiment III}

The injection of GnRH induced ovulation in $43.5 \%(10 / 23)$ of the animals from the two groups, and emergence of a new follicular wave occurred $2.2 \pm 0.2$ days after GnRH administration in $74 \%$ of the heifers (17/23). In the heifers with no emergence of a new wave the follicles kept growing after $\mathrm{GnRH}$ injection.

The sharp decline in progesterone concentrations indicates that PGF $2 \alpha$ injection caused luteolysis in all heifers from the GP$\mathrm{d} 7$ and GPE-d7 groups (Figure 2).

In the control group (GP-d7) ovulation rate was $75 \%(9 / 12)$ while in the GPE-d7 group, PGF $2 \alpha$ followed $24 \mathrm{~h}$ later by EB administration induced ovulation in $63.6 \%$ (7/11) of the heifers. Two heifers (one from GP-d7 and one from GPE-d7) ovulated 2 days before PGF $2 \alpha$ injection and one ovulated on the day when PGF2 $\alpha$ was administered (GPE-d7). Furthermore, three heifers from GP-d7 and four from GPE-d7 did not ovulate until 7 days after PGF2 $\alpha$ administration. The injection of estradiol benzoate induced estrus behavior in all heifers from GPE-d7 in spite of the fact that 4 of 9 heifers did not ovulate after injection of EB. In the control group (GP-d7), only $58.3 \%$ of the heifers were observed in heat.

Excluding the animals that ovulated before $(\mathrm{N}=2)$ or on the day $(\mathrm{N}=1)$ of PGF $2 \alpha$ administration, the intervals from PGF2 $\alpha$ injection to ovulation were $103.7 \pm 10.1$ and $66.5 \pm 3.5 \mathrm{~h}$ for GP-d7 and GPE-d7, respectively. Consequently, the administration of EB induced ovulation $37 \mathrm{~h}$ earlier when 
compared to the control group $(\mathrm{P}<0.05)$ and caused a more precise synchrony of ovulation, which occurred within a period of 18 and $66 \mathrm{~h}$, respectively, for GPE-d7 and GP$\mathrm{d} 7(\mathrm{P}<0.05)$. The pregnancy rate after timed AI was 27.3\% (GPE-d7), as opposed to $41.6 \%$ in heifers inseminated after estrus detection (GP-d7).

\section{Experiment IV}

The injection of GnRH induced ovulation in 7 heifers ( 2 from GP-d6 and 5 from
GPh-d6) and follicular atresia in 11 of 21 heifers $(5,2$ and 4, respectively, from GPd6, GPh-d6 and GPE-d6). The emergence of a new follicular wave occurred $2.2 \pm 0.2$ days after GnRH injection in 74\% (17/23) of the heifers.

Progesterone concentrations indicate that 14,71 and $100 \%$ of the heifers from GP-d6, GPh-d6 and GPE-d6 did not respond to PGF2 $\alpha$ treatment, respectively (Figure 3). However, the percentage of animals detected in heat was 100,0 and $85.7 \%$ for GP-d6, GPh-d6 and GPE-d6, respectively.

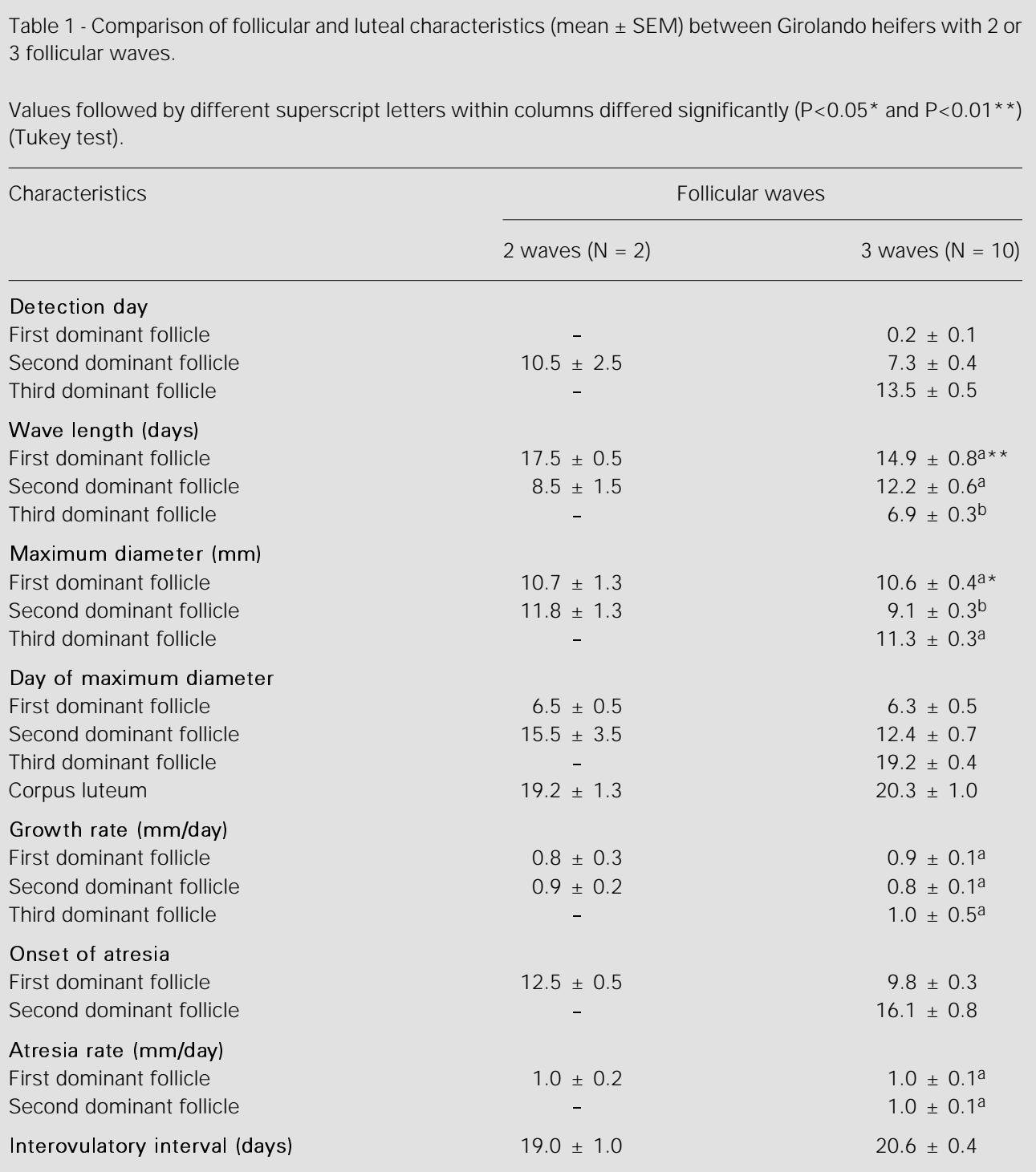


Figure 1 - Progesterone concentrations $(\mathrm{ng} / \mathrm{ml}$, mean $\pm \mathrm{SEM})$ in Girolando heifers during treatment with GnRH $(8 \mu \mathrm{g}$, day 0$)$, PGF2 $\alpha$ (25 mg, day 7) and hCG (3000 IU, day 8, GPh-d7, $\mathrm{N}=$ 14).
After the hormonal treatment all heifers from the GP-d6 and GPh-d6 groups ovulated, as opposed to only one heifer from the GPE-d6 group (63.3 $\mathrm{h}$ after the EB injection).

The interval from PGF2 $\alpha$ injection to ovulation in the GPh-d6 group (56.6 $\pm 1.9 \mathrm{~h})$ was significantly shorter when compared to the GP-d6 group $(101.9 \pm 7.2 \mathrm{~h}, \mathrm{P}<0.01)$. Therefore, injection of hCG induced ovulation $67.4 \mathrm{~h}$ earlier $(\mathrm{P}<0.01)$ when compared to the control group and induced a more precise synchrony of ovulation, which oc-

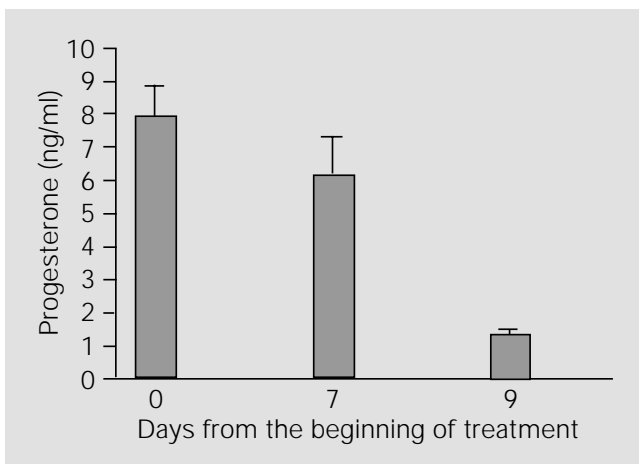

Figure 2 - Progesterone concentrations $(\mathrm{ng} / \mathrm{ml}$, mean $\pm \mathrm{SEM})$ in Girolando heifers during treatment with GnRH (8 $\mu$ g, day 0$)$, PGF2 $\alpha$ (25 mg, day 7, GP-d7, N $=12$ ) and estradiol benzoate (0.75 mg, day 8, GPE-d7, $\mathrm{N}=$ $11)$.

Figure 3 - Progesterone concentrations $(\mathrm{ng} / \mathrm{ml}$, mean $\pm \mathrm{SEM})$ in Girolando heifers during treatment with $\mathrm{GnRH}(8 \mu \mathrm{g}$, day 0$)$, PGF2 $\alpha$ (25 mg, day 6, GP-d6, N $=7$ ) and hCG (3000 IU, day 7, GPh-d6, $N=7$ ) or estradiol benzoate (0.75 mg, day 7, GPE-d6).
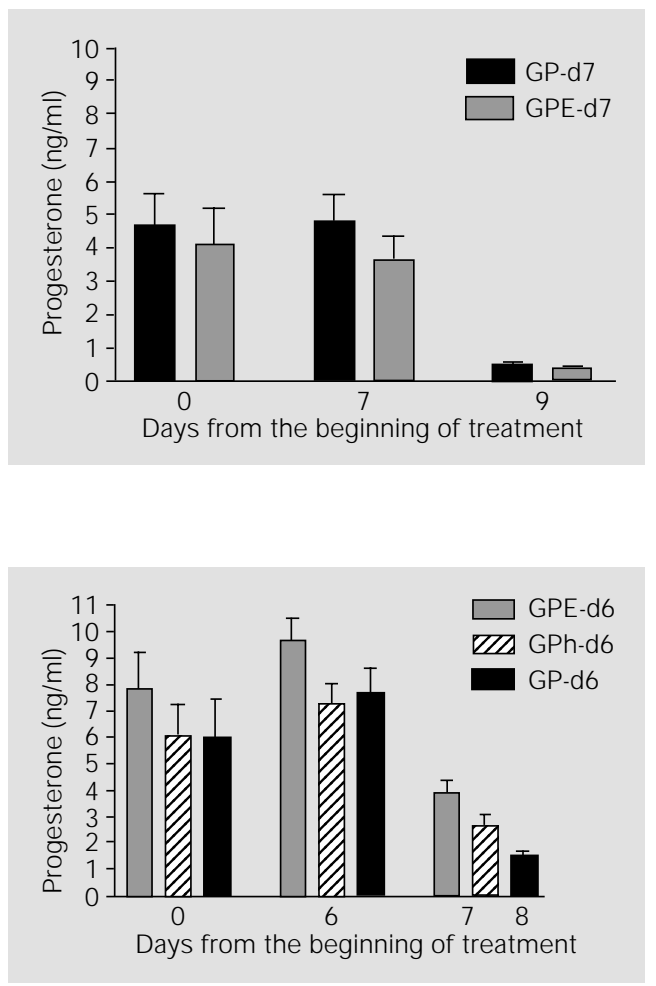

curred within a period of 12 and $52 \mathrm{~h}$ for GPh-d6 and GP-d6, respectively. The pregnancy rate was the same (42.8\%) for heifers submitted to timed AI (GPh-d6) and for those that were bred after detection of estrus (GP-d6). None of the animals from GPE-d6 became pregnant.

\section{Discussion}

In the present study the follicular dynamics of Girolando heifers was characterized primarily by the presence of three follicular waves. These patterns of follicular growth are similar to those observed in Bos taurus $(13,14)$ and Bos indicus $(9,15)$ heifers. Other investigators have reported the rare occurrence of one or four follicular waves $(9,13$ 16) and the predominance of two waves (17). The reasons for variations between two and three follicular waves are not clear. However, some factors such as pregnancy (16), puberty (18), diet (19), heat stress (20) and energy balance (21) may influence follicular dynamics.

The detection of the first, second and third follicular waves in 3-wave Girolando heifers $(0.2 \pm 0.1,7.3 \pm 0.4$ and $13.5 \pm 0.5$ days, respectively) occurred a little earlier (especially the third wave) compared with those of Holstein heifers $(1.9 \pm 0.3,9.4 \pm 0.5$ and $16.1 \pm 0.7$ days; $-0.5 \pm 0.3,9.0 \pm 0.0$ and $16.0 \pm 1.1$ days, and approximately 4,12 and 16 days; $13,14,17)$. The occurrence of follicular waves was very close to that observed in Nelore heifers $(1.6 \pm 0.2,9.1 \pm 0.5$ and $15.1 \pm 0.5$ days; 9 ). As previously reported for European (6.1 days, 5.9 days, 6.8 days; $13,14,17)$ and Zebu breeds (6.9 days; 9), the length of the third follicular wave (6.9 days) was significantly $(\mathrm{P}<0.01)$ shorter than that of the other waves.

The maximum diameter of dominant follicles (10 to $13 \mathrm{~mm}$ ) observed in Girolando heifers was smaller than that reported for Bos taurus heifers (14 to $20 \mathrm{~mm}, 13$ to 18 $\mathrm{mm}, 14$ to $16 \mathrm{~mm} ; 13,17,22)$ and similar to 
that reported for Bos indicus heifers $(10 \mathrm{~mm}$, $12 \mathrm{~mm} ; 9,15)$. The second dominant follicle, developing during the luteal phase, was significantly smaller $(\mathrm{P}<0.01)$ than the others in 3 -wave Girolando heifers. This result agrees with those obtained for European (14) and Zebu cattle (9).

The maximum CL diameter for 3-wave Girolando heifers (19 to $20 \mathrm{~mm}$ ) was comparable to that obtained for Zebu heifers (17 to $18 \mathrm{~mm} ; 9,15)$. However, the size tended to be smaller than that for Bos taurus (25 to 30 $\mathrm{mm} ; 22)$. Thus, the size of dominant follicles and CL of Girolando heifers (Gir x Holstein) may be similar to those of Zebu cattle and smaller than those of Bos taurus breeds. However, the pattern of growth and turnover of dominant follicles is similar for Zebu and European breeds.

Injection of the GnRH agonist at random stages of the estrous cycle caused ovulation in 33 to $50 \%$ of Girolando heifers and induced a new follicular wave 2 to 3 days after its administration in $91 \%$ of the heifers (49/ 58). A similar ovulation rate has been reported for European heifers $(54 \% ; 6)$ and Zebu cows (33.3\%; 23), while in European cows Pursley et al. (7) showed a higher percentage of ovulation $(>85 \%)$ about 2 days after the first GnRH injection.

$\mathrm{GnRH}$ administration induces ovulation or atresia (24) depending on the stage of follicular development (4). Silcox et al. (25) reported that $\mathrm{GnRH}$ induced ovulation in $100 \%$ of growing follicles ( $>10 \mathrm{~mm}), 33 \%$ of follicles in the plateau phase and $0 \%$ (no ovulation) of atretic follicles. In addition, LH receptors decrease as the dominant follicle develops from growth to the plateau and regression phases (26) and as atresia is clearly being manifested (27).

In most Girolando heifers (100\% Exp. II, $74 \%$ Exp. III and $86 \%$ Exp. IV) the GnRH agonist induced a new follicular wave at approximately 2 days after its administration, and as a consequence of this follicular synchronization, $86 \%$ of the heifers had a dominant follicle $(>8.0 \mathrm{~mm})$ at the time of PGF2 $\alpha$ injection (day 6 or 7). The use of GnRH, in addition to inducing ovulation or atresia, stimulates recruitment of follicles directly by follicle-stimulating hormone (FSH) release within 2 to $4 \mathrm{~h}$ after its administration (28) and/or indirectly by an increase in FSH concentration occurring 1 to 2 days after removal of the dominant follicle (29) that contains FSH inhibitory factors such as inhibin (27).

Administration of PGF $2 \alpha$ induced luteolysis in $85 \%$ (day 7, Exp. II), $100 \%$ (day 7 , Exp. III) and $38 \%$ (day 6, Exp. IV) of the Girolando heifers. In Experiment IV, PGF $2 \alpha$ injection did not cause luteolysis in 5 of 7 heifers from GPh-d6 or in the 7 heifers from GPE-d6, while most animals from GP-d6 presented luteolysis (6/7).

Injection of the primary GnRH agonist induced the formation of an accessory $C L$ in 5, 0 and 2 heifers from GPh-d6, GPE-d6 and GP-d6, respectively. Considering that PGF2 $\alpha$ is not efficient in causing luteolysis during the first 4 days after ovulation (30), a possible explanation for the reduced number of heifers that presented luteolysis in the GPhd6 group is the presence of accessory CL (5/ 7) that are too young (4 days old) to respond to PGF $2 \alpha$ administration. However, it is surprising that none of the animals from the GPE-d6 group presented luteolysis in spite of the absence of accessory CL and the presence of functional CL (progesterone $>6.0$ $\mathrm{ng} / \mathrm{ml}$ ). Pursley et al. (7) reported the absence of luteolysis in 6 of 24 Holstein heifers treated with PGF $2 \alpha 7$ days after GnRH agonist injection. In Nelore cows (31), PGF $2 \alpha$ administration did not induce estrus in 54\% of the animals even in the presence of a functional CL (progesterone $>5.0 \mathrm{ng} / \mathrm{ml}$ ) in 23 of 28 animals.

The administration of a second dose of GnRH 24 to $48 \mathrm{~h}$ after PGF $2 \alpha$ causes a more precise synchronization of ovulation in both Bos taurus (7,32) and Bos indicus cows (33) and permits timed artificial insemination 
$(3,5,32,34,35)$. Pursley et al. (7) reported that all Holstein cows and $75 \%$ of the heifers ovulated within a period of 24 to $32 \mathrm{~h}$ after the second GnRH administration. In another study using an AI protocol of GnRH - 7 days - PGF $2 \alpha-30$ to $36 \mathrm{~h}-\mathrm{GnRH}-16$ to $24 \mathrm{~h}$, the same authors (3) showed that the pregnancy rate after this treatment was similar to that for the control group (37.8 vs 38.9\%). Additionally, Roy and Twagiramungu (8) observed a high pregnancy rate $(62.2 \%)$ after timed AI in beef heifers treated with a similar protocol(GnRH-PGF-GnRH) except that GnRH was administered 6 days after PGF2 $\alpha$ and the second dose of GnRH was injected 46 to 48 after PGF $2 \alpha$.

In the present study, the second dose of GnRH was replaced by estradiol benzoate or hCG. Estradiol benzoate in the absence of progesterone $(<1.0 \mathrm{ng} / \mathrm{ml})$ has been shown to induce an LH surge approximately 16 to $24 \mathrm{~h}$ after its administration (36). However, EB in the presence of a functional CL or when administered with exogenous progestagens decreases gonadotrophin secretion and induces atresia of the dominant follicle (37). In contrast, GnRH administration induces a short LH surge (approximately $5 \mathrm{~h} ; 28$ ), while plasma levels of hCG (LH-like activity) continue to be detectable up to $66 \mathrm{~h}$ after its im injection (32). In Girolando heifers treated with hCG (GPh-d6) ovulation occurred $67.4 \mathrm{~h}$ earlier $(\mathrm{P}<0.01)$ compared to control (GP-d6, Exp. IV) and was better synchronized since most of it occurred within a period of 12 (GPh-d6) or $17 \mathrm{~h}$ (GPh-d7). The pregnancy rate obtained after timed AI (50\% in GPh-d7 and $42.8 \%$ in GPh-d6) was close to that obtained in Holstein heifers (56.1\%) after the GnRH-PGF-hCG protocol (hCG was injected $48 \mathrm{~h}$ after PGF2 $\alpha$ and all heifers were inseminated $16 \mathrm{~h}$ after hCG; 32). However, a small number of Girolando heifers was used. Consequently, these results must be confirmed with a larger number of animals.

The use of EB to synchronize ovulation in Girolando heifers was not as effective as hCG, because only one heifer ovulated in the GPE-d6 group and 2 of 11 heifers ovulated before the end of the hormonal treatments (GPE-d7). Excluding these 2 heifers, EB administration (GPE-d7) induced ovulation $37 \mathrm{~h}(\mathrm{P}<0.05)$ earlier compared to control heifers (GP-d7) and induced a better synchrony of ovulation, which occurred within a period of 66 and $18 \mathrm{~h}$ for GP-d7 and GPE$\mathrm{d} 7$, respectively. The low ovulation rate observed in GPE-d6 can be explained by the fact that none of the heifers presented luteolysis after PGF $2 \alpha$ administration, showing that EB in the presence of elevated progesterone concentrations $(>2.0 \mathrm{ng} / \mathrm{ml})$ did not induce an LH surge and ovulation. On the other hand, although five of seven heifers from GPh-d6 did not undergo luteolysis, all of them ovulated after hCG injection. This may be explained by the fact that hCG, which has LH-like activity, induces ovulation acting directly on the follicles $(32,38)$.

In the control groups the percentage of animals showing estrus was 58.3 and $100 \%$ for GP-d7 and GP-d6, respectively. These results agree with those obtained in other studies in which PGF2 $\alpha$ administered 6 or 7 days after GnRH injection induced heat in 70 to $83 \%$ of the animals $(4,5)$.

Estradiol benzoate injection induced estrus in most Girolando heifers $(100 \%$ in GPE-d 7 and $86 \%$ in GPE-d6) while none of them showed estrus after hCG injection (GPhd6). It has been shown that administration of estrogens induces behavioral estrus in cattle (39), whereas GnRH agonist reduces the occurrence of spontaneous estrus due to functional alterations in the dominant follicles (1), which could lead to lower estradiol concentrations in the blood stream (4). Considering that both GnRH and hCG induce ovulation through LH-like activity, it is possible that hCG reduces spontaneous estrus in a similar manner as GnRH.

The pregnancy rates obtained after EB administration in groups GPE-d7 (27.3\%) 
and GPE-d6 (0\%) were lower than those reported for Nelore cows treated with GPEd7 protocol $(45.5 \%$; 35$)$ and closer to those observed in Nelore heifers $(\mathrm{N}=64)$ treated with the GPE-d6 protocol (33\%; Barros CM, Figueiredo RA and Fernandes $\mathrm{P}$, unpublished results). The high percentage of heifers showing estrus after EB administration (GPE-d7 and GPE-d6) followed by low pregnancy rates after timed $\mathrm{AI}$ indicates that the occurrence of heat in response to estradiol benzoate injection may not be linked to the actual time of LH surge or ovulation time. In spite of the small number of heifers used, the low pregnancy rates observed after GPE-d6 and GPE-d7 indicate that these treatments are not as promising for heifers as they are for adult cows (35).

In Experiment III, $14.3 \%$ of the animals ( 2 in GPE-d7 and 1 in GP-d7) ovulated before the injection of PGF $2 \alpha$, while no animal from GPE-d6 or GP-d6 exhibited estrus or ovulated before PGF $2 \alpha$ administration. Results reported by Canadian researchers (8) indicate that a 6-day interval between GnRH and PGF2 $\alpha$ injection improves estrus synchronization and reduces the occurrence of estrus before PGF2 $\alpha$ administration.

Schmitt et al. (32) treated Holstein heifers with the GnRH-PGF-GnRH protocol for timed AI and reported a lower pregnancy rate in animals injected with GnRH $24 \mathrm{~h}$ after PGF2 $\alpha(25.8 \%)$ when compared to those that received GnRH $48 \mathrm{~h}$ after prostaglandin (45.5\%). Additionally, they observed that the low pregnancy rate was associated with a high incidence $(34.8 \%)$ of heifers returning earlier to estrus ( $<16$ days) after timed AI in the group of animals that received GnRH 24 h after PGF $2 \alpha$. In contrast, delaying the second GnRH injection (48vs $24 \mathrm{~h}$ ) allowed the ovulatory follicle to be exposed for a longer time to the increased basal pulsatile release of $\mathrm{LH}$. This may have permitted the ovulatory follicle to differentiate into a normal $\mathrm{CL}$ with a higher ste- roidogenic capacity. This normal CL was capable of maintaining pregnancy and consequently the number of animals returning earlier to estrus decreased (32). Likewise, it may be possible to improve pregnancy rates in Girolando heifers treated with $\mathrm{GnRH}$ PGF-EB by extending to $48 \mathrm{~h}$ the interval between PGF $2 \alpha$ administration and EB injection.

Although hCG (GPh-d6 and GPh-d7 groups) and EB (GPE-d6 and GPE-d7 groups) were administered $24 \mathrm{~h}$ after PGF2 $\alpha$, the synchronization of ovulation and pregnancy rates after hCG treatment was much better than that observed after EB administration. At least two factors may have contributed to these results: hCG is capable of inducing ovulation even in the presence of a functional CL $(32,40)$, and second the CL induced by hCG is larger and produces more progesterone than the GnRH-induced CL (40). Consequently, it may have a better capacity to maintain pregnancy.

In summary, hCG administration in both protocols, GPh-d6 and GPh-d7, was effective in synchronizing ovulation and allowed successful timed AI in crossbred heifers. On the other hand, estradiol benzoate synchronized ovulation in only 5 of 11 Girolando heifers from the GPE-d7 group and in none from the GPE-d6 group, which led to low pregnancy rates after timed AI. However, since a small number of Girolando heifers was used to determine pregnancy rates, pregnancy rates should be confirmed with a larger number of animals.

\section{Acknowledgments}

The authors express their appreciation to Zeide Sab, Americana Farm, São Paulo, for providing the cows and support. We are also indebted to Dra. Magaly Manzo (Maracay, Venezuela) for providing progesterone antiserum and to Luiz A. Oliveira for technical assistance. 


\section{References}

1. Thatcher WW, Macmillan KL, Hansen PJ \& Drost M (1989). Concepts for regulation of corpus luteum function by the conceptus and ovarian follicles to improve fertility. Theriogenology, 31: 149-164.

2. Thatcher WW, Drost $M$, Savio JD, Macmillam KL, Entwistle KW, Schmitt EJ , de la Sota RL \& Morris GR (1993). New clinical uses of $\mathrm{GnRH}$ and its analogues in cattle. Animal Reproduction Science, 33: 27-36.

3. Pursley JR, Wiltbank MC, Stevensom J S, Ottobre J S, Barverick HA \& Andersom LL (1997). Pregnancy rates per artificial insemination for cows and heifers inseminated at a synchronized ovulation or synchronized estrus. J ournal of Dairy Science, 80: 295-300.

4. Twagiramungu $\mathrm{H}$, Guilbault LA \& Dufour JJ (1995). Synchronization of ovarian follicular waves with a gonadotropin-releasing hormone agonist to increase the precision of estrus in cattle: A review. J ournal of Animal Science, 73: 3141-3151.

5. Burke JM, de la Sota RL, Risco CA, Staples CR, Schmitt EJ P \& Thatcher WW (1996). Evaluation of timed insemination using a gonadotropin-releasing hormone agonist in lactating dairy cows. J ournal of Dairy Science, 79: 1385-1393.

6. Wiltbank MC, Pursley J R, Fricke PM, Vasconcelos J , Guenther J N, Gibbons J R \& Ginther OJ (1996). Development of Al and ET programs that do not require detection of estrus using recent information on follicular growth. Proceedings of the American Embryo Transfer Association, USA, 15: 23-44.

7. Pursley JR, Mee $M O \&$ Wiltbank MC (1995). Synchronization of ovulation in dairy cows using PGF $2 \alpha$ and GnRH. Theriogenology, 44: 915-923.

8. Roy GL \& Twagiramungu H (1996). A fixed time Al program using the GnRH-PGFGnRH method for beef females. J ournal of Animal Science, 74 (Suppl 1): 222 (Abstract).

9. Figueiredo RA, Barros CM, Pinheiro $\mathrm{OL} \&$ Soler J MP (1997). Ovarian follicular dynamics in Nelore breed (Bos indicus). Theriogenology, 47: 1489-1505.

10. Ambrose J D, Pires MFA, Moreira F, Diaz T, Binelli M \& Thatcher WW (1998). Influence of deslorelin (GnRH-agonist) implant on plasma progesterone, first wave dominant follicle and pregnancy in dairy cattle. Theriogenology, 50: 1157-1170.

11. SAS. Statistical Analysis System (1989). SAS/STAT User's Guide, Release 6.12 .
SAS Institute Inc., Cary, NC.

12. Campbell RC (1974). Statistics for Biologists. 2nd edn. Cambridge University Press, London.

13. Savio J D, Keenan L, Boland MP \& Roche J $F$ (1988). Pattern of growth of dominant follicles during the oestrous cycle of heifers. J oumal of Reproduction and Fertility, 83: 663-671.

14. Sirois J \& Fortune J E (1988). Ovarian follicular dynamics during the estrous cycle in heifers monitored by real-time ultrasonography. Biology of Reproduction, 39: 308317.

15. Rhodes FM, De'ath $\mathrm{G} \&$ Entwistle KW (1995). Animal and temporal effects on ovarian follicular dynamics in Brahman heifers. Animal Reproduction Science, 38: 265-277.

16. Murphy MG, Boland MP \& Roche JF (1990). Pattern of follicular growth and resumption of ovarian activity in postpartum beef suckler cows. J ournal of Reproduction and Fertility, 90: 523-533.

17. Ginther OJ , Knopf L \& Kastelic J P (1989). Temporal associations among ovarian events in cattle during oestrous cycles with two and three follicular waves. J ournal of Reproduction and Fertility, 87: 223230.

18. Evans ACO, Adams GP \& Rawlings NC (1994). Follicular and hormonal development in prepubertal heifers from 2 to 36 weeks of age. Journal of Reproduction and Fertility, 103: 463-470.

19. Murphy MG, Enright WJ \& Crowe MA (1991). Effect of dietary intake on pattern of growth of dominant follicles during the oestrous cycle in beef heifers. J ournal of Reproduction and Fertility, 92: 333-338.

20. Wolfenson $D$, Thatcher WW, Badinga $L$, Savio J D, Meidan R, Lew BJ , Braw-Tal R \& Berman A (1995). Effect of heat stress on follicular development during the estrous cycle in lactating dairy cattle. Biology of Reproduction, 52: 1106-1113.

21. Lucy MC, Savio J D, Badinga L, de la Sota RL \& Thatcher WW (1992). Factors that affect ovarian follicular dynamics in cattle. J ournal of Animal Science, 70: 3615-3626.

22. Adams GP, Kot K, Smith CA \& Ginther OJ (1993). Effect of the dominant follicle on regression of its subordinates in heifers. Canadian J ournal of Animal Science, 73: 267-275.

23. Moreira MBP (1997). Sincronização da ovulação em vacas da raça Nelore. Master's thesis, Instituto de Biociências, Universidade Estadual Paulista, Botucatu, SP.
24. Macmillan KL \& Thatcher WW (1991). Effects of an agonist of gonadotropin-releasing hormone on ovarian follicles in cattle. Biology of Reproduction, 45: 883889.

25. Silcox RW, Powell KL \& Kiser TE (1993). Ability of dominant follicle (DF) to respond exogenous GnRH administration is dependent on their stage of development. J ournal of Animal Science, 71: 219 (Abstract).

26. Rolosson MM, Crim J W, Silcox RW \& Kiser TE (1994). Density of [ ${ }^{125}$ I] hCG binding to the dominant follicle of the first wave of the estrous cycle in cows. J ournal of Dairy Science, 77 (Suppl 1): 231 (Abstract).

27. Guilbault LA, Rouiller $P, M$ atton $P$, Glencross RG, Beard AJ \& Knight PG (1993). Relationships between the level of atresia and inhibin contents ( $\alpha$ subunit and $\alpha$ - $\beta$ dimer) in morphologically dominant follicles during their growing and regressing phases of development in cattle. Biology of Reproduction, 48: 268-276.

28. Chenault J R, Kratzert DD, Rzepkowski RA $\&$ Goodwin MC (1990). LH and FSH response of Holstein heifers to fertirelin acetate, gonadorelin and buserelin. Theriogenology, 34: 81-88.

29. Adams GP, Matteri RL, Kastelic JP, Ko J CH \& Ginther OJ (1992). Association between surges of follicle-stimulating hormone and the emergence of follicular waves in heifers. J ournal of Reproduction and Fertility, 94: 177-188.

30. Rowson LEA, Tervit R \& Brand A (1972) The use of prostaglandin for synchronization of estrus in cattle. J ournal of Reproduction and Fertilily, 29: 145-149.

31. Pinheiro OL, Barros CM, Figueiredo RA, Valle ER, Encarnação RO \& Padovani CR (1998). Estrous behavior and the estrusto-ovulation interval in Nelore cattle (Bos indicus) with natural estrus or estrus induced with prostaglandin $\mathrm{F}_{2} \alpha$ or norgestomet and estradiol valerate. Theriogenology, 49: 667-681.

32. Schmitt EJ P, Diaz TC, Drost $M$, Roomes $C \&$ Thatcher WW (1996). Use of a GnRH agonist on human chorionic gonadotropin for timed insemination in cattle. J ournal of Animal Science, 74: 1084-1091.

33. Gambini ALG, Moreira MBP, Castilho C \& Barros CM (1998). Dinâmica folicular e sincronização da ovulação em vacas da raça Gir. Revista Brasileira de Reprodução Animal, 22: 201-210.

34. Momcilovic D, Archbald LF, Walters A 
Tran T, Kelbert D, Risco C \& Thatcher WW (1998). Reproductive performance of lactating dairy cows treated with gonadotrophin-releasing hormone $(\mathrm{GnRH})$ and/ or prostaglandin F2 $\alpha$ (PGF2 $\alpha$ ) for synchronization of estrus and ovulation. Theriogenology, 50: 1131-1139.

35. Fernandes P (1998). Inseminação artificial com tempo predeterminado em vacas Nelore tratadas com acetato de buserelina, prostaglandina F2 $\alpha$ e benzoato de estradiol. Master's thesis, Faculdade de Medicina Veterinária e Zootecnia, Universidade Estadual Paulista, Botucatu, SP.

36. Lammoglia MA, Short RE, Bellows RE, Bellows RA, Macneil MD \& Hafs HD
(1998). Induced and synchronized estrus in cattle: dose titration of estradiol benzoate in peripubertal heifers and postpartum cows after treatment with an intravaginal progesterone-releasing insert and prostaglandin $\mathrm{F}_{2} \alpha$. J ournal of Animal Science, 76: 1662-1670.

37. Bo GA, Adams GP, Pierson RA, Tribulo HE, Caccia M \& Mapletoft RJ (1994). Follicular wave dynamics after estradiol-17ß treatment of heifers with or without a progestogen implant. Theriogenology, 41: 1555-1569.

38. Seguin $B E$, Oxender WD \& Britt $J H$ (1977). Effect of human chorionic gonadotropin-releasing hormone on corpus lu- teum function and estrous cycle duration in dairy heifers. American J ournal of Veterinary Research, 38: 1153-1156.

39. McGuire WJ , Larson RL \& Kiracofe GH (1990). Syncro-mate B induced estrus in ovariectomized cows and heifers. Theriogenology, 34: 33-37.

40. Schmitt EJ P, Diaz TC, Barros CM, de la Sota RL, Drost $M$, Fredriksson EW, Staples CR, Thorner R \& Thatcher WW (1996). Differential response of the luteal phase and fertility in cattle following ovulation of the first-wave follicle with human chorionic gonadotropin or an agonist of gonadotropin-releasing hormone. J ournal of Animal Science, 74: 1074-1083. 